\title{
Tingkat Finansial Literasi Masyarakat Kota Gorontalo dan Faktor-Faktor Yang Mempengaruhinya
}

\author{
Boby Rantow Payu ${ }^{1}$ \\ Fakultas Ekonomi, Universitas Negeri Gorontalo \\ e-mail:bobby_rantow@yahoo.com \\ Selvi $^{2}$ \\ Fakultas Ekonomi, Universitas Negeri Gorontalo
}

\begin{abstract}
ABSTRAK
Scam investment phenomena raises in Indonesian people in recent years, includes in Gorontalo. This shows that level of understanding and knowledge of the people about financial investment product is still low. Therefore, this research aims to measure to what extent level of financial literacy of people in Gorontalo City. This research was conducted by considering the importance of financial literacy as factors that determines mostly economic growth thus it is an agenda campaigned by Bank of Indonesia and Financial Service Authority (OJK). This research aims to investigate level of financial literacy of Gorontalo City people based on factors of demography, social and economic. In addition, it also aims to obtain applicable model and strategy of approach in terms of improving level of financial literacy of the people. This is a descriptive quantitative research. Then, it applies descriptive and crosstab analysis. Research finding reveals that level of financial literacy of Gorontalo City people is good. For conventional product, it is categorized very good while for non-conventional product, level of financial literacy of people in Gorontalo Province is very low. Therefore, more intense socialization and education are needed by mean of minimizing potency of scam investment.
\end{abstract}

Keywords: financial literacy, investment, financial

\begin{abstract}
Scam investment phenomena raises in Indonesian people in recent years, includes in Gorontalo. This shows that level of understanding and knowledge of the people about financial investment product is still low. Therefore, this research aims to measure to what extent level of financial literacy of people in Gorontalo City. This research was conducted by considering the importance of financial literacy as factors that determines mostly economic growth thus it is an agenda campaigned by Bank of Indonesia and Financial Service Authority (OJK). This research aims to investigate level of financial literacy of Gorontalo City people based on factors of demography, social and economic. In addition, it also aims to obtain applicable model and strategy of approach in terms of improving level of financial literacy of the people. This is a descriptive quantitative research. Then, it applies descriptive and crosstab analysis. Research finding reveals that level of financial literacy of Gorontalo City people is good. For conventional product, it is categorized very good while for non-conventional product, level of financial literacy of people in Gorontalo Province is very low. Therefore, more intense socialization and education are needed by mean of minimizing potency of scam investment.
\end{abstract}

Keywords: financial literacy, investment, financial

\section{PENDAHULUAN}

Literasi keuangan merupakan

kebutuhan dasar bagi setiap orang agar terhindar dari masalah keuangan. Kesulitan keuangan bukan hanya fungsi dari pendapatan semata (rendahnya pendapatan), kesulitan keuangan juga dapat muncul jika terjadi kesalahan dalam pengelolaan keuangan (miss-management) seperti kesalahan penggunaan kredit, dan tidak adanya perencanaan keuangan.

Keterbatasan finansial dapat menyebabkan stress, dan rendahnya kepercayaan diri, bahkan untuk sebagian 
keluarga kondisi tersebut dapat berujung pada perceraian. Memiliki literasi keuangan, merupakan hal vital untuk mendapatkan kehidupan yang sejahtera, dan berkualitas. Lebih lanjut dijelaskan bahwa literasi keuangan bersama-sama dengan kemampuan membaca dan matematik merupakan kunci untuk dapat menjadi konsumen yang cerdas, mengelola kredit dan mendanai pendidikan tinggi, saving dan investing dan warga negara yang bertanggungjawab.

Kebutuhan individu dan produk finansial yang semakin kompleks menuntut masyarakat untuk memiliki financial literacy yang memadai. Memiliki penguasaan ilmu serta skill di bidang keuangan mendorong individu untuk memahami dan terlibat isu-isu nasional di bidang keuangan seperti biaya perawatan kesehatan, pajak, investasi dan memiliki akses ke dalam sistem keuangan. Kurangnya literasi keuangan dapat mengakibatkan rendahnya akses ke lembaga keuangan dan menghambat kemakmuran, sebab menurut calon anggota Komisioner Otoritas Jasa Keuangan, Soetiono, akses yang luas ke sistem keuangan atau sistem keuangan yang mencakup usaha mikro, masyarakat miskin dan kaum wanita, serta rumah tangga produktif, maka bisa menurunkan perbedaan pendapatan diantara masyarakat (Kompas, 13 Juni 2012).

Indonesia termasuk salah satu negara dengan kondisi literasi keuangan masyarakatnya rendah. Menurut Anggota Dewan Komisioner Bidang Edukasi dan Perlindungan Konsumen OJK Kusumaningtuti Soetiono yang dikutip Kusuma (2014) mengatakan bahwa tingkat literasi keuangan masyarakat Indonesia masih rendah dibandingkan dengan Singapura dan Malaysia, bahkan di bawah Thailand. Di Malaysia, tingkat literasi keuangan masyarakatnya mencapai $66 \%$,
Singapura mencapai 98\%, sedangkan Thailand mencapai angka $73 \%$, sementara Indonesia masih pada angka $28 \%$. Bahkan hal ini diperkuat oleh hasil survei indeks MasterCard (2014) yang menyatakan bahwa tingkat literasi keuangan Indonesia merupakan yang terendah ke-3 dari negara-negara Asia Pasifik.

Survei World Bank tahun 2010 menunjukkan separuh penduduk Indonesia tidak memiliki akses atas layanan lembaga keuangan formal. Hal ini mengindikasikan bahwa sistem keuangan belum berjalan secara optimal serta masih adanya ruang untuk perbaikan dalam rangka peningkatan akses masyarakat kepada layanan lembaga keuangan. Melihat kondisi tersebut, pada bulan Juni 2012, Bank Indonesia bekerjasama dengan Sekretariat Wakil Presiden - Tim Nasional Percepatan Penanggulangan Kemiskinan (TNP2K) dan Badan Kebijakan Fiskal Kementerian Keuangan mengeluarkan Strategi Nasional Keuangan Inklusif. Dalam rangka pelaksanaan program Keuangan Inklusif, Bank Indonesia (BI) bersama pemerintah menyusun Strategi Nasional Keuangan Inklusif (SNKI) yang salah satu pilar utamanya adalah Edukasi Keuangan yang bertujuan untuk meningkakan tingkat melek keuangan masyarakat Indonesia (financial literacy).

Berdasarkan latar belakang yang dipaparkan di atas, masalah yang ingin diteliti dalam penelitian ini dirumuskan sebagai berikut :

1. Sejauh mana tingkat melek keuangan (financial literacy) masyarakat di Kota Gorontalo?

2. Faktor-faktor apa saja yang berkontribusi terhadap financial literacy masyarakat Kota Gorontalo?

3. Upaya apa saja yang dapat ditempuh untuk meningkatkan tingkat financial literacy masyarakat di Kota Gorontalo? 


\section{METODE}

Tujuan utama penelitian ini adalah memetakan kondisi financial literacy masyarakat di Kota Gorontalo beserta faktor-faktor yang mempengaruhinya. Dari hasil tersebut diharapkan dapat didesain metode edukasi keuangan yang dapat diterapkan untuk meningkatkan financial literacy masyarakat. Untuk mencapai tujuan tersebut maka penelitian ini didesain dengan menggunakan pendekatan deskriptif eksplanasi.

Lokasi penelitian akan dilakukan di wilayah Kota Gorontalo. Hal ini didasarkan pertimbangan bahwa Kota Gorontalo merupakan ibukota Provinsi Gorontalo sekaligus sebagai pusat ekonomi Provinsi Gorontalo. Selain itu kondisi masyarakat Kota Gorontalo yang majemuk dilihatdari struktur ekonomi, sosial, dan demografi sehingga diharpakan bisa merepsentasikan kondisi masyarakat Gorontalo pada umumnya. Adapun objek penelitian adalah individu dan rumah tangga di wilayah Kota Gorontalo.

Populasi dalam penelitian ini adalah masyarakat di Kota Gorontalo baik individu maupun rumah tangga. Kriteria responden yang diamati adalah berumur antara 17-65 tahun. Pemilihan responden dilakukan secara acak dengan menggunakan pendekatan Stratified Systematic Random Sampling dengan menggunakan teknik alokasi Proportional to Population Size (PPS) dengan mempertimbangkan penyebaran penduduk di setiap kecamatan di Kota Gorontalo.

Teknik analisis data yang akan digunakan dalam penelitian ini adalah sebagai berikut.

\section{Analisis Deskriptif}

Analisis desktiptif ini digunakan sebagai analisis awal untuk menggambarkan kondisi financial literacy masyarakat Kota Gorontalo saat ini.
Indikator yang akan dianalisis secara deskriptif adalah indikator yang berkaitan dengan demografi, status sosial, kondisi ekonomi serta pertanyaan yang berkaitan dengan pemahaman mengenai keuangan dan produk keuangan. Dengan analisis deskripsi ini dapat diketahui informasi umum mengenai rumah tangga dan karakteristik sosial, ekonomi dan demografi setiap anggota rumah tangga. Sedangkan untuk masyarakat individual, dapat diketahui informasi tentang pengetahuan, sikap dan perilaku individu yang berkaitan dengan keuangan.

\section{Analisis Faktor}

Analisis ini akan diarahkan untuk melihat bobot dari faktor-faktor yang berkontribusi terhadap tingkat financial literacy masyarakat. Analisis faktor merupakan prosedur statistik untuk mereduksi atau meringkas data, dari sejumlah variabel-variabel yang saling independen satu dengan yang lain sehingga bisa dibuat satu atau beberapa kumpulan variabel yang lebih sedikit dari jumlah variabel awal, yang disebut sebagai faktor dan masih memuat sebagian besar informasi yang terkandung dalam variabel awal. Di dalam analisis faktor, variabelvariabel awal tidak dikelompokkan menjadi variabel bebas dan tidak bebas, sebaliknya sebagai penggantinya seluruh set hubungan interdependen antar variabel tersebut diteliti. Dalam penelitian ini, variabel-variabel yang dimaksudkan penjelasan di atas adalah aspek-aspek yang terkait dengan tingkat financial literacy masyarakat. Adapun teknik reduksi variabel yang akan digunakan adalah Principal Component Analysis (PCA).

\section{HASIL DAN PEMBAHASAN \\ Karakteristik Responden}

Sebaran responden penelitian berdasarkan jenis kelamin dan status 
perkawinan dapat dilihat dalam tabel berikut ini.

Tabel 1. Jenis Kelamin dan Status Perkawinan

\begin{tabular}{clc}
\hline \multicolumn{2}{c}{ Indikator Demografi } & $\%$ \\
\hline \hline \multirow{2}{*}{ Jenis Kelamin } & Laki-Laki & $41.18 \%$ \\
& Perempuan & $58.82 \%$ \\
\hline \hline \multirow{2}{*}{ Status Pernikahan } & Menikah & $54.90 \%$ \\
& Belum Menikah & $45.10 \%$ \\
\hline
\end{tabular}

Berdasarkan tabel diatas, komposisi responden dalam penelitian ini didominasi oleh responden berjenis kelamin perempuan sebanyak $58,82 \%$. Sedangkan dilihat dari status perkawinan, sebanyak $54,9 \%$ responden berstatus telah menikah.

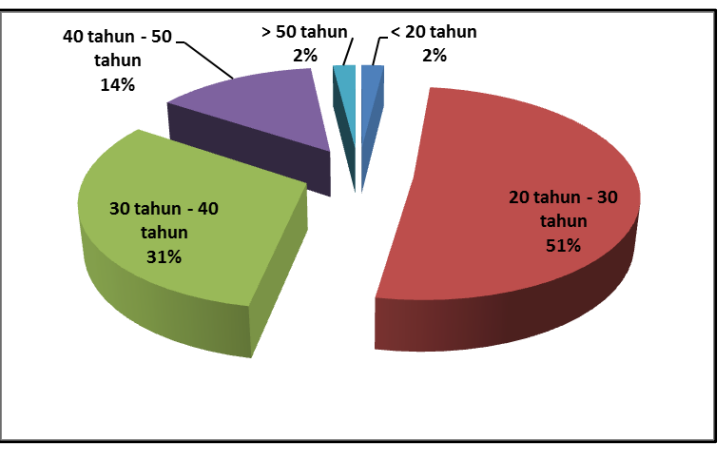

Gambar 1. Usia

Dilihat dari komposisi sebaran umur yang dimiliki, responden yang menjadi sampel dalam penelitian ini didominasi oleh kelompok usia muda (dibawah 40 tahun) dimana sebanyak $51 \%$ berusia antara 20-30 tahun dan sebanyak 31\% berusia antara 30-40 tahun dan sisanya sebanyak $2 \%$ berusia dibawah 20 tahun. Adapun responden yang berusia diatas 40 tahun sebanyak $18 \%$ yang didominasi oleh responden yang berusia 40-50 tahun sebanyak $14 \%$.

Sebaran responden berdasarkan tingkat pendidikan yang dimiliki dapat dilihat dalam gambar berikut ini.

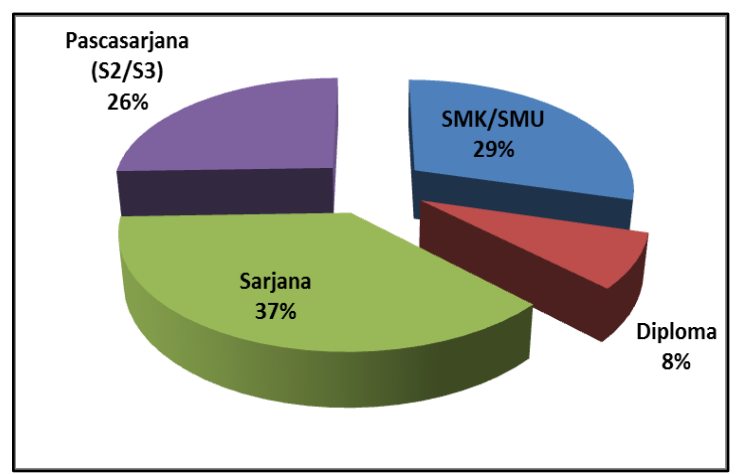

Gambar 2. Tingkat Pendidikan

Berdasarkan gambar diatas terlihat bahwa sebagian besar responden yang diamati dalam penelitian ini memiliki latar belakang pendidikan tinggi (Diploma, Sarjana, maupun Pasca Sarjana). Responden yang berlatar pendidikan Diploma sebanyak 8\%, berlatar pendidikan Sarjana sebanyak $37 \%$ dan berlatar pendidikan Pasca Sarjana (S2/S3) sebanyak 26 orang. Adapun sisanya sebanyak $29 \%$ responden berlatar belakang pendidikan SMA/SMK/ Sederajat.

Sebaran responden berdasarkan profesi yang dijalani saat ini dapat dilihat dalam gambar berikut ini.

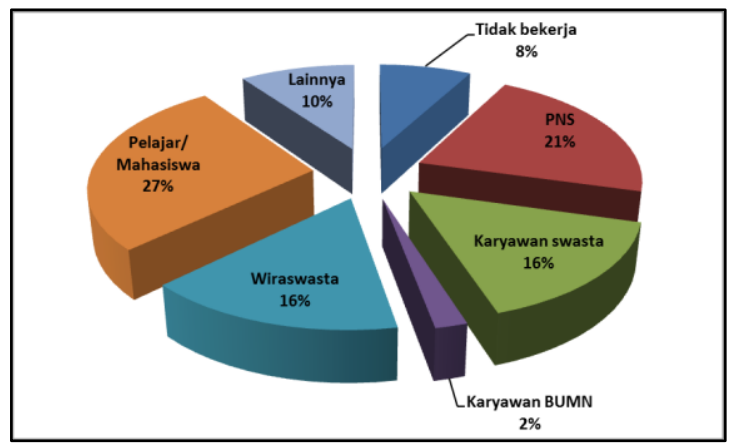

Gambar 3. Profesi

Berdasarkan gambar diatas terlihat bahwa mayoritas responden yang diamati dalam penelitian ini berprofesi atau berstatus sebagai pelajar/mahasiswa yakni sebanyak $27 \%$. Selanjutnya sebanyak $21 \%$ responden berprofesi sebagai Pegawai Negeri Sipil (PNS), berprofesi sebagai 
karyawan (swasta maupun BUMN) sebanyak 18\%, berprofesi sebagai wiraswasta sebanyak $16 \%$, dan sebanyak $10 \%$ responden berprofesi lainnya (sopir, ibu rumah tangga, dll). Adapun responden yang tidak bekerja sebanyak $8 \%$.

Sebaran responden berdasarkan penghasilan yang diperoleh per bulan dapat dilihat dalam gambar berikut ini.

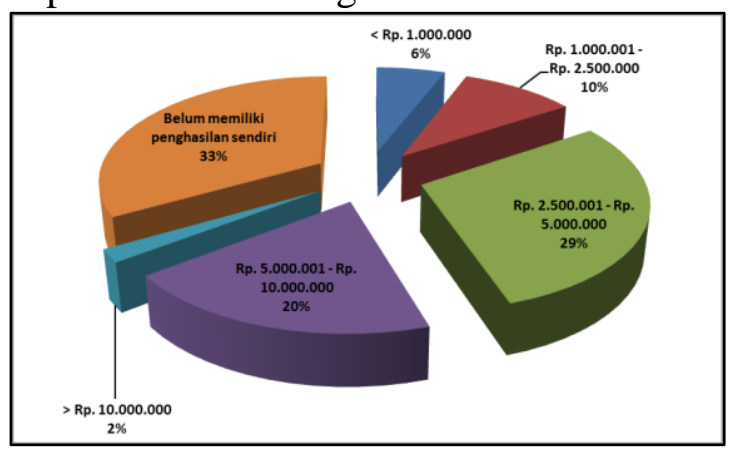

Gambar 4. Penghasilan

\section{Pengetahuan Umum Tentang Produk- Produk Keuangan dan Investasi}

Dewasa ini jumlah produk keuangan dan investasi yang ditawarkan kepada masyarakat sudah cukup bervariasi. Selain produk-produk keuangan yang konvensional (tabungan, pinjaman) juga terdapat produk-produk lain baik yang ditawarkan oleh lembaga keuangan perbankan maupun yang non-perbankan. Sangat bervariasinya produk-produk keuangan dan investasi tersebut harus disikapi dengan bijak oleh masyarakat agar nantinya tidak menimbulkan kerugian bagi masyarakat itu sendiri. Tingkat pengenalan masyarakat Kota Gorontalo mengenai berbagai macam produk keuangan dan investasi dapat dilihat dalam grafik berikut ini.

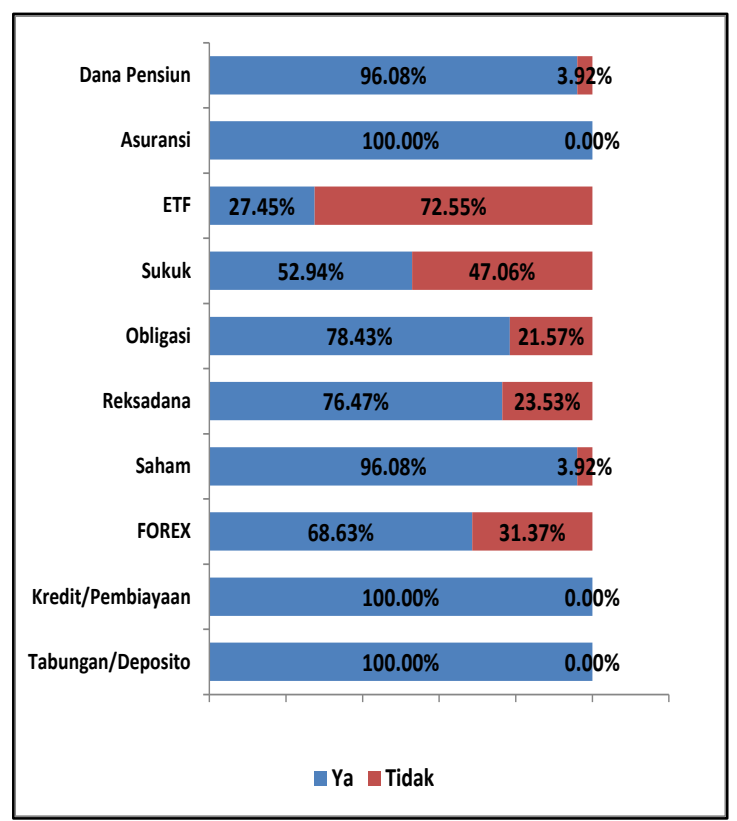

Gambar 5. Tingkat pengenalan masyarakat Kota Gorontalo mengenai berbagai macam produk keuangan dan investasi

Berdasarkan grafik diatas terlihat bahwa tingkat pengenalan masyarakat Kota Gorontalo terhadap produk keuangan cukup bervariasi. Untuk produk-produk keuangan yang bersifat konvensional (tabungan, pinjaman, asuransi, dan dana pensiun), tingkat pengenalan masyarakat sangat baik. Namun untuk produk-produk keuangan non-konvensional, tingkat pengenalan yang dimiliki oleh masyarakat masih relatif rendah bila dibandingkan dengan produk keuangan konvensional.

Untuk produk investasi saham tingkat pengenalan masyarakat Gorontalo sudah baik. Sedangkan untuk jenis investas obligasi, reksadana, dan forex, tingkat pengenalan masyarakat Gorontalo sudah cukup baik. Sedangkan untuk jenis investasi sukuk yang notabene merupakan produk obligasi yang berprinsip syariah, tingkat pengenalan masyarakat masih rendah. Demikian pula untuk produk investasi ETF (Exchange Traded Fund), tingkat pengenalan masyarakat masih sangat rendah. Hal ini dikarenakan produk investasi ini masih merupakan hal yang 
relatif baru di Indonesia. Sedangkan untuk tingkat pemahaman masyarakat Gorontalo terhadap berbagai produk keuangan dan investasi tersebut dapat dilihat dalam grafik berikut ini.

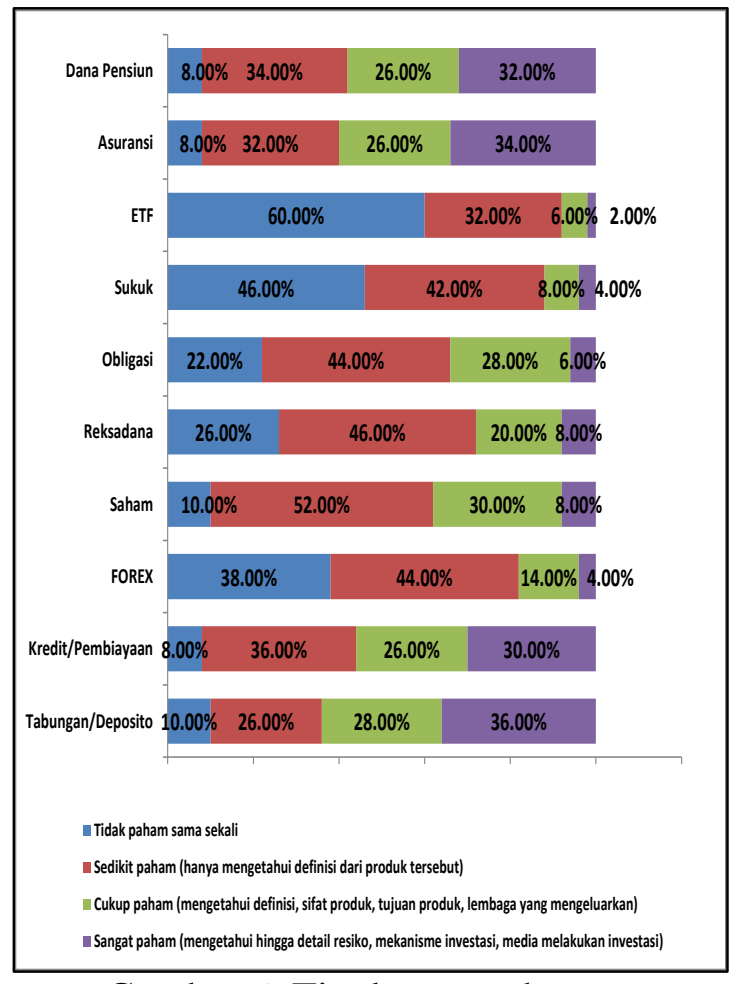

Gambar 6. Tingkat pemahaman masyarakat Gorontalo terhadap berbagai produk keuangan dan investasi

Berdasarkan grafik diatas terlihat bahwa dari 10 produk keuangan/investasi yang ditanyakan kepada responden, masyarakat Kota Gorontalo hanya mengetahui dengan baik produk keuangan yang bersifat konvensional. Untuk produk tabungan/deposito, persentase responden yang memahami dengan baik (minimal memahami definisi produk hingga detail profil produk keuangan) mencapai $64 \%$ dan untuk produk kredit/pembiayaan mencapai $56 \%$. Sementara untuk produk asuransi, $60 \%$ responden telah memahami dengan baik dan untuk produk dana pensiun sebanyak $58 \%$ responden telah memahami dengan baik.
Adapun untuk produk keuangan dan investasi non-konvensional (saham, reksadana, forex, dll), tingkat pengetahuan masyarakat relatif masih sangat rendah. Untuk produk investasi saham, hanya sebanyak 38\% masyarakat yang memiliki pengetahuan yang baik mengenai profik dan tujuan dari investasi ini. Demikian pula untuk obligasi, hanya $34 \%$ masyarakat yang memahami dengan baik, dan untuk produk reksadana hanya sebanyak $28 \%$ masyarakat yang memiliki pemahaman yang baik mengenai definisi, profil, dan tujuan investasi. Sedangkan untuk produk investasi sukuk, yang merupakan bentuk obligasi berprinsip syariah, hanya sebanyak $12 \%$ yang memiliki pemahaman yang baik mengenai profil dan tujuan dari investasi sukuk.

Adapun untuk produk keuangan nonkonvensional lain yang berupa transaksi di pasar uang atau foreign exchange (FOREX), tingkat pengetahuan dan pemahaman masyarakat juga masih rendah. Hanya 18\% masyarakat yang memiliki pemahaman baik mengenai produk keuangan ini. Dari $18 \%$ persen tersebut, sebanyak $14 \%$ hanya mengetahui definisi dan lembaga yang menyelenggarakan. Sedangkan responden yang memahami hingga mekanisme transaksi, media melakukan transaksi serta resiko yang dapat ditimbulkan hanya sebanyak $4 \%$.

Sementara untuk produk investasi ETF yang merupakan pengembangan dari reksadana saham hanya sebanyak $8 \%$ responden yang telah memiliki pemahaman yang baik mengenai produk investasi ini. Dari $8 \%$ tersebut, sebanyak $6 \%$ memiliki pemahaman hanya sebatas definisi dan lembaga yang menyelenggarakan sedangkan responden yang memiliki pemahaman hingga ke mekanisme transaksi dan resiko yang ditimbulkan hanya sebanyak $2 \%$. 
Selain tingkat pengetahuan terhadap berbagai jenis produk keuangan dan investasi, penelitian ini juga bertujuan untuk memperoleh informasi mengenai aksesbilitas masyarakat terhadap produk keuangan dan investasi yang dimaksud. Hal ini dimaksudkan untuk melihat sejauh mana tingkat keterlibatan dan kepemilikan masyarakat terhadap produk keuangan dan investasi tersebut.

Sebaran responden berdasarkan kepemilikan atau keikutsertaan dalam kegiatan investasi pada produk keuangan dapat dilihat dalam grafik berikut ini.

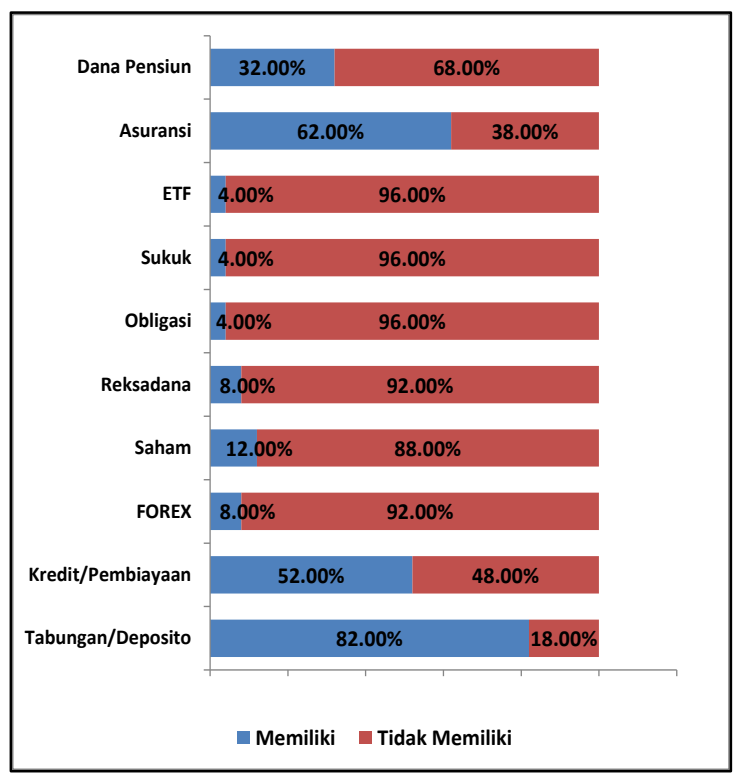

Gambar 7. Sebaran responden berdasarkan kepemilikan atau keikutsertaan dalam kegiatan investasi pada produk keuangan

Berdasarkan grafik diatas terlihat bahwa tingkat aksesbilitas masyarakat yang tertinggi terdapat pada produk tabungan/deposito denga tingkat aksesbilitas mencapai $82 \%$. Ini berarti sebanyak $82 \%$ responden memiliki rekening di perbankan dan sisanya sebanyak $18 \%$ belum memiliki rekening tabungan di lembaga perbankan. Sedangkan untuk kredit/pembiayaan, tingkat aksesbilitas masyarakat hanya sebesar 52\%. Untuk produk asuransi, tingkat aksesbilitas masyarakat mencapai $62 \%$ dan untuk produk dana pensiun tingkat aksesbilitas masyarakat hanya sebesar $32 \%$.

Sementara untuk produk keuangan non-konvensional, tingkat aksesbilitas masyarakat sangat rendah dimana mayoritas responden tidak pernah memiliki atau terlibat dalam kegiatan investasi pada instrumen tersebut. Dari 6 produk keuangan non-konvensional yang diamati, tingkat aksesbilitas masyarakat terhadap instrumen saham, reksadana, dan forex yang relatif agak tinggi dibandingkan dengan instrumen investasi lainnya (obligasi, sukuk, dan ETF).

\section{Pengetahuan dan Aksesbilitas Terhadap Produk Perbankan}

Dari 10 produk keuangan/investasi yang diamati dalam penelitian ini, produk keuangan yang memiliki aksesbilitas tertinggi adalah produk tabungan/ deposito dan kredit/pembiayaan. Tingginya aksesbilitas tersebut disebabkan oleh tingkat pengetahun masyarakat serta kemudahan dalam memperoleh informasi mengenai produk-produk keuangan tersebut.

Adapun alasan utama masyarakat dalam memilih produk tabungan dapat dilihat dalam grafik berikut ini. 


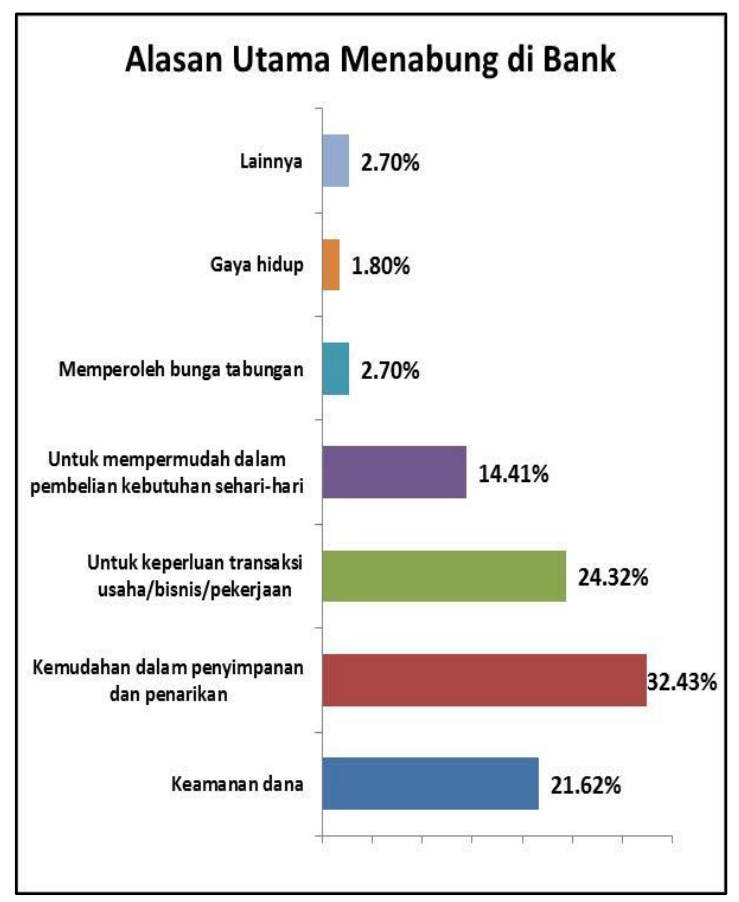

Gambar 8. Alasan utama menabung di Bank

Berdasarkan grafik diatas terlihat bahwa alasan utama masyarakat dalam memilih produk tabungan adalah karena mudah dalam melakukan penyimpanan dan penarikan terhadap dana yang mereka miliki. Jangkauan lembaga perbankan yang sangat luas serta dukungan sarana berupa ATM, setor tunai, internet banking dan sms banking merupakan faktor yang turut mendukung kemudahan tranaksi masyarakat sehingga akan meningkatkan aksesbilitas masyarakat terhadap produk tabungan.

Selain kemudahan dalam penyimpanan dan penarikan, alasan utama masyarakat untuk menabung adalah untuk mendukung kebutuhan dalam transaksi usaha/bisnis/pekerjaan. Selain itu pertimbangan keamanan dana menjadi alasan utama masyarakat lebih memilih produk tabungan yang ditawarkan oleh bank. Adanya penjaminan yang dilakukan oleh Lembaga Penjamin Simpanan (LPS) terhadap dana nasabah yang disimpan di bank menjadi salah satu faktor yang memperkuat keyakinan masyarakat akan keamanan dana mereka di bank.

Tiga alasan utama ini yang membuat banyak masyarakat yang bahkan memiliki lebih dari satu rekening tabungan. Kepemilikan lebih dari satu rekening tabungan ini terutama untuk menyesuiakan dengan kebutuhan setiap transaksi. Dengan adanya pemisahan rekening tabungan masyarakat merasa akan lebih mudah dalam melakukan pengelolaan keuangan. Untuk sebaran kepemilikan tabungan oleh masyarakat Gorontalo dapat dilihat dalam gambar berikut ini.

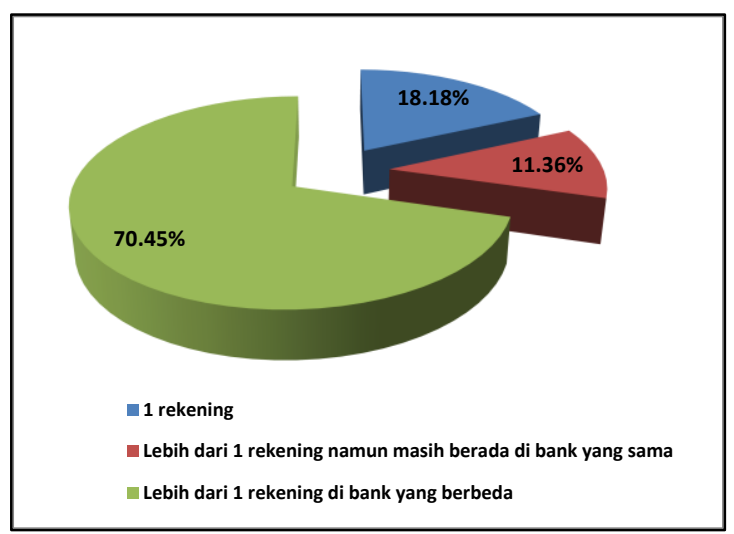

Gambar 9. Sebaran kepemilikan tabungan oleh masyarakat Gorontalo

Berdasarkan gambar diatas terlihat bahwa sebanyak $81,82 \%$ responden memiliki lebih dari satu rekening tabungan dimana sebanyak $70,45 \%$ memiliki rekening di bank yang berbeda dan sebanyak 11,36\% memiliki lebih dari satu rekening namun masih di lembaga perbankan yang sama. Sedangkan responden yang hanya memiliki satu rekening tabungan sebanyak $18,18 \%$.

Adapun pola masyarakat dalam menabung dapat dilihat dalam gambar berikut ini. 


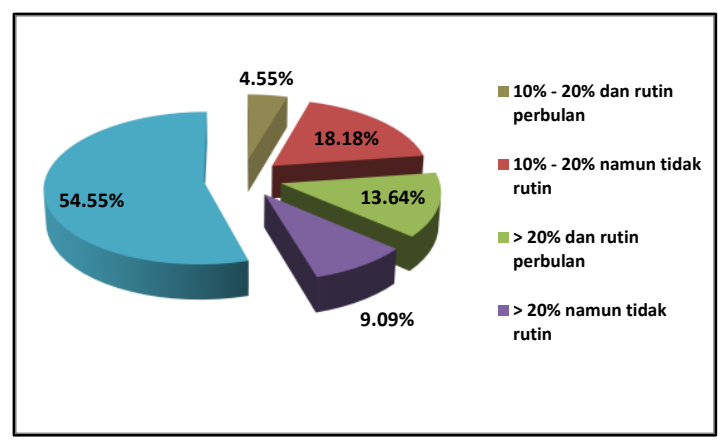

Gambar 10. Pola masyarakat dalam menabung

Dari gambar di atas terlihat bahwa sebanyak 54,55\% masyarakat melakukan kegiatan menabung tergantung dari sisa dana yang dimiliki setiap bulan. Atau dengan kata lain prosentase pendapatan yang disisihkan untuk tabungan tidak pasti disesuaikan dengan kebutuhan dana dan kondisi keuangan. Sementara sisanya sebanyak $45,45 \%$ telah menyisihkan bagian pendapatan sesuai prosentase tertentu. Sebanyak 22,73\% masyarakat menyisihkan $10 \%-20 \%$ dari pendapatan untuk ditabung dan sebanyak 22,73\% menyisihkan lebih dari $20 \%$ penghasilan per bulan untuk ditabung.

\section{PENUTUP}

\section{Kesimpulan}

Berdasarkan hasil analisis data yang telah dilakukan sejauh ini dapat diambil beberapa kesimpulan sebagai berikut.

1. Secara umum tingkat literasi masyarakat Gorontalo terhadap produk keuangan dan investasi dapat dikatakan cukup baik.

2. Untuk produk keuangan konvensional (tabungan, kredit, asuransi, dana pensiun), literasi masyarakat Gorontalo sudah sangat baik. Namun untuk produk keuangan nonkonvensional, tingkat literasi masyarakat Gorontalo masih sangat rendah.
3. Rendahnyya literasi masyarakat Gorontalo untuk produk-produk keuangan non-konvensional ini merupakan salah satu faktor yang menyebabkan masyarakat mudah untuk tergiur pada tawaran investasi yang menawarkan return tinggi.

\section{Saran}

Berdasarkan kesimpulan sementara yang diperoleh maka peneliti memberikan beberapa saran sebagai berikut :

1. Perlu adanya upaya dari lembaga keuangan terkait untuk lebih mensosialisasikan berbagai produk keuangan/investasi yang ditawarkan kepada masyarakat.

2. Untuk meningkatkan literasi masyarakat terhadap produk keuangan non- konvensional perlu dilakukan melibatkan perguruan tinggi dan lembaga keuangan terkait melalui kegiatan seminar atau sosialisasi mengenai berbagai alternatif investasi selain di bank.

Untuk kalangan mahasiswa, perlu adanya optimaliasi peran galeri investasi yang dimiliki oleh kampus untuk lebih giat melakukan sosialisasi investasi pasar modal khususnya kepada mahasiswa.

\section{DAFTAR PUSTAKA}

Bank Indonesia dan Lembaga Demografi UI. (2014). Financial Literacy Baseline Survey. Jakarta

Bank Indonesia. (2013). Evolusi Kerangka Kebijakan Financial Inclusion. Jakarta

Bank Indonesia. (2014). Booklet Keuangan Inklusif. Jakarta

Chairuddin Syah Nasution. (2014). Kebijakan Keuangan Inklusif : Negara Maju vs Negara Berkembang. Jakarta

OECD. (2014). PISA 2012 Results: Students and Money: Financial Literacy Skills for the 21st Century 
(Volume VI). Programme for International Student Assessment, OECD Publishing.

OJK. (2014). Sambutan Dewan Komisioner Otoritas Jasa Keuangan Pada Gerakan Nasional Cinta (GeNTa) Pasar Modal. Jakarta

Kementrian Keuangan Republik Indonesia. (2013). Financial Inclusion : Strategi Nasional Keuangan Inklusif. Jakarta

USAID, DEFINIT \& SEADI. (2013). Developing an Financial Literacy Index. SEADI Discussion Paper No.

11. Jakarta 